Nevena P. Ceković

https://doi.org/10.18485/analiff.2018.30.1.7

Univerzitet u Beogradu

$811.131 .1^{\prime} 42$

Filološki fakutet

Originalni naučni rad

Primljen: 24.04.2018.

Prihvaćen: 11.08.2018.

\title{
DIDAKTIČKI MATERIJALI ZA ITALIJANSKI KAO L2: (NE)EKSPLICITNI FOKUS NA DISKURSNIM MARKERIMA
}

\begin{abstract}
Analizom 110 udžbenika za italijanski kao L2 i priručnika iz glotodidaktike, publikovanih u nešto više od pola veka, otkrili smo da se svega $10 \%$ udžbenika, nastalih u proteklih desetak godina i namenjenih isključivo srednjim i naprednim nivoima kompetencije, eksplicitno fokusira na diskursne markere (DM). Mišljenja smo da je Zajednički evropski okvir načinio prekretnicu u prodoru DM u udžbenike: tek u onima datiranim nakon 2001. godine, kada je Okvir objavljen, ovi razgovorni elementi postaju predmet eksplicitne pažnje. Izuzetak od rasprostranjene prakse pružanja malobrojnih i sporadičnih aktivnosti sa DM, najčešće u samo jednog didaktičkoj jedinici, čini 5 udžbenika opisanih u radu u kojima se sledi tradicionalni obrazac Prezentacija - Praksa - Produkcija i to kroz različite prezentacione, analitičke i produktivne aktivnosti uglavnom usmerene na povezivanje formi i funkcija markera, s tim da se kao pogodne za realizaciju sistematskog pristupa ispoljavaju i druge (refleksija, role-play, dramatizacija). Nalazeći da je reč o primerima uravnotežene frekventnosti i cikličnosti u tretiranju DM, ipak zaključujemo da je i dalje premalo takvih udžbenika i njihovih autora, kao i da je količina pažnje usmerene na markere u ovim materijalima nedovoljna, u smislu ograničenog broja i obima predloženih aktivnosti, odnosno izostanka eksplicitnijeg fokusa.
\end{abstract}

Ključne reči: diskursni markeri, italijanski L2, didatički materijali.

\section{Uvod}

Didaktičkim materijalima nesumnjivo pripada značajan udeo u svakom nastavnom procesu vezanom za drugi/strani jezik (L2/Ls), pa i onom koji uključuje diskursne markere (DM), kao važno obeležje učenikove pragmatičko-diskursne kompetencije (Council of Europe, 2001). Ovi pragmatič-

Katedra za italijanistiku, Studentski trg 3, Beograd, n.cekovic@fil.bg.ac.rs 
ki polifunkcionalni elementi (Bazzanella, 1995, 2008; Ceković, 2011, 2016; Ceković \& Radojević, 2016; Ceković \& Janićijević, 2017; Moderc, 2015), reči i izrazi poput allora, cioè, ecco, insomma, per esempio kojima obiluje razgovorni jezik, čine bitan faktor u dostizanju pragmatičke fluentnosti u L2 (House, 2013), omogućavajući učeniku da ,podmaže“ tj. organizuje i strukturira vlastiti diskurs, ali i da upravlja interakcijom sa sagovornikom, primera radi, umešno uzimajući, zadržavajući ili ustupajući svoju reč.

U istraživanjima na polju primenjene lingvistike i teorije usvajanja L2 poslednjih decenija DM se posvećuje sve više pažnje, a rezultati ukazuju da je reč o kategoriji koja se teško i kasno usvaja, kao i da je neophodno primeniti sistematski pristup ovim elementima u nastavnom procesu (Fung \& Carter, 2007; Hellermann \& Vergun, 2007; Müller, 2005). Imajući u vidu i nalaze studija koji skreću pažnju na to da su u poređenju sa autentičnim diskursom udžbenici često defektni u pogledu zastupljenosti pragmatičkih fenomena (npr. zatvaranja konverzacije, Bardovi-Harlig, Hartford et al., 1991; Tateyama, Kasper et al., 1997), što može biti jedan od uzorka koji otežava usvajanje date jezičke pojave, zanimalo nas je da $\mathrm{u} \mathrm{radu}^{2}$ preispitamo zastupljenost DM u didaktičkim materijalima i da otkrijemo u kojoj meri i na koji način je ova građa u njima prezentovana. ${ }^{3}$

Fokusiraćemo se prvenstveno na analizu udžbenika za učenje italijanskog kao L2, od kojih su većina dostupni i na srpskom tržištu (manji broj je kreiran upravo s ciljem da se zadovolje specifične potrebe srbofonih učenika), i u različitim vremenskim periodima su primenjivani ili se i dalje primenjuju u učionici, na kursevima jezika. Zapravo, analizom ćemo obuhvatiti 110 udžbenika i nekolicinu specijalizovanih priručnika za učenje italijanskog kao L2, nastalih u periodu od 1960. do 2015. godine i namenjenih kursevima prvenstveno za odrasle, ali i za omladinu i decu. ${ }^{4}$

2 Najvažniji rezultati ovog istraživanja prvobitno su usmeno predočeni 30. juna 2017. godine na međunarodnoj konferenciji AATI (American Association of Teachers of Italian) u Palermu (Italija).

3 Ovom prilikom ostavićemo po strani druge resurse koji su učeniku i nastavniku na raspolaganju, npr. gramatike (v. Ceković, 2016), rečnike (v. Ceković \& Radojević, 2016) ili Silabuse (v. Ceković, 2016).

4 Jasno je da spisak nije potpun, premda smo nastojali da obuhvatimo što veći obim i broj didaktičkih materijala. 


\section{Analiza materijala: odsustvo fokusa ili neeksplicitni fokus}

U većini ovih udžbenika i priručnika ne nalazimo nikakvog eksplicitnog pomena o $\mathrm{DM}^{5}$ (up. Živković-Mandolfo, 1960; Roncari \& Brighenti, 1972; Katerinov \& Boriosi, 1973; Jeremić \& Turconi, 1976, 1977; Rossi-Hace \& Zaina, 1983, 1988, 1989a/b; Radicchi \& Mezzedimi, 1989; Perini, 1991; Katerinov \& Boriosi Katerinov, 1992; Vučo \& Moderc, 1994, 1995, 1997, 1999, 2003, 2004, 2005; Silvestrini, Bura et al., 1995, 1996; Stipčević \& Franchi, 1996; Terić, 1996a/b; Azzarà, Scarpocchi et al., 1996; Bettoni \& Vicentini, 1997; Torchia, 1997; Conforti \& Cusimano, 1997, 2003; Jones \& Marmini, 1998; Zurula, 1998; Cammarota, 1999; Amati \& Bacci, 1999, 2002; Mezzadri, 2000; Marin, 2000, 2005; Mezzadri \& Balboni, 2001, 2005a/b; Ziglio \& Rizzo, 2001, 2014; Balì \& Rizzo, 2002, 2003, 2014; Marin \& Magnelli, 2001, 2003, 2004, 2006, 2009; Orlandino, Rizzo et al., 2005; Tamponi, 2006; Blatešić, 2007; Blatešić \& Stojković, 2008; Patota \& Romanelli, 2008a; Gruppo lingua, 2008, 2009; Guastalla \& Naddeo, 2010, 2012; De Savorgnani \& Cordera Alberti, 2011; Ricci, 2011; Marin \& Albano, 2011a/b, 2012; Faraci, De Luca et al., 2011a/b, 2012; Blatešić, Stojković et al., 2011; D’Angelo, Pedol et al., 2012b; Stojković \& Zavišin, 2013; Balì \& Ziglio, 2015).

Za razliku od DM, kategorija konektora čini se, međutim, prilično zastupljenom u analiziranim udžbenicima i priručnicima, pre svega u onima novijeg datuma i to kroz raznovrsnu tipologiju vežbanja (up. Gruppo Meta, 1993: 31, 193; Borgarelli Bacoccoli, 1996: 24, 34, 49, 99, 102, 391 393; La Cara \& Preziuso, 1998: 14, 28-29, 44; Cammarota, Fasoglio et al., 2000: 141; Naddeo \& Trama, 2000: 93; Bailini \& Consonno, 2002: 47-49,

5 Pod eksplicitinim pominjanjem podrazumevamo transparentno ukazivanje na ovu kategoriju, između ostalog i upotrebom termina diskursni marker i ostalih ekvivalenata, te smo stoga isključili druge načine prezentovanja sadržaja kojima je ova kategorija implicitno obuhvaćena, npr. kroz obradu gramatičkih kategorija kao što su prilozi, uzvici i dr. Konektore, međutim, nismo sasvim izuzeli iz analize, budući da ih je u navedenim primerima u udžbenicima često nemoguće pouzdano razlučiti od DM (up., npr. Bozzone Costa (2004: 200) i Bozzone Costa, Ghezzi et al. (2005: III) gde se ove dve kategorije naporedo navode, odnosno Piotti \& De Savorgnani (2006: 172) gde se, očito usled previda, u sadržaju precizira da se obrađuju DM, a unutar date lekcije ilustruju se isključivo konektori). Sem toga, zanemarili smo i aktivnosti koje na nefokusiran način uključuju DM, npr. vežbe sa slušanjima u kojima govornici koriste markere ili dopunjavanja koja se, pored ostalog, odnose i na DM (neki od primera takvih aktivnosti mogu se naći u Pernas, Gillani et al., 2011, a za analizu nekolicine udžbenika koja uključuje i takve primere upotrebe DM, v. Imazu \& Valeri, 2004). 
135-137; Ignone, 2002: 9, 43, 117, 129; Bozzone Costa, 2004: 200, 201, 240; Bozzone Costa, Ghezzi et al., 2005: 2, 20, 36, 56, 74, 98, 138, 154, 174; Chiappini \& De Filippo, 2005: 67, 128-130; Piotti \& De Savorgnani, 2006: 172; Diaco, Parma et al., 2007: 16; Piantoni, Ghezzi et al., 2007: 2, 20, 38, 56, 74, 94; De Biasio \& Garofalo, 2008: 27, 90; Marin, 2008: 82; Patota \& Romanelli, 2008b: 15, 50, 208; Fragai, Fratter et al., 2010: 72, 87, 103, 136, 199; Ghezzi, Piantoni et al., 2009: 7, 22, 34, 49, 62, 74; De Savorgnani \& Bergero, 2010: 70; Guastalla \& Naddeo, 2011: 162, 186, 198; Caon, Ceccon et al., 2011: 134; La Grassa, 2011: 120, 123; Bettinelli, Della Putta et al., 2011: 93; D’Angelo, Pedol et al., 2012a: 132; Bozzone Costa, Piantoni et al., 2013: 31, 44, 50, 71, 93, 138-143; La Grassa, Delitala et al., 2013: 45, 84, 121, 139, 157; Anzivino, D’Angelo et al., 2013: 23, 33).

Pa ipak, u manjem broju udžbenika otkrivamo latentan, netransparentan pristup DM i to kroz vežbanja u kojima se pre svega ukazuje na funkcije koje DM, obično definisani kao (idiomatski) ,izrazi“, mogu vršiti, a među kojima se najčešće pominje privlačenje sagovornikove pažnje, kao i zahtevanje potvrde od sagovornika. Zanimljivo je da su i neki od udžbenika starijeg datuma prepoznali važnost funkcija markera i počeli, doduše diskretno, da na njih skreću pažnju. Takav je primer In italiano (Chiuchiù, Minciarelli et al., 1990: 418), gde se u odeljku posvećenom komunikativnim činovima sugeriše upotreba izraza - E poi?, - E allora? E dopo?, - Continua!, - Dai! Continua! za podsticanje sagovornika da nastavi izlaganje, odnosno izraza - E allora come è andata a finire?,-Insomma, come è finita la cosa? u vidu molbe upućene sagovorniku da zaključi svoju priču. Ili Uno (Gruppo Meta, 1992: 43, 126), gde se među funkcionalnim sadržajima, u zadatku sa transformacijom prema ponuđenom primeru, ukazuje na upotrebu mah za distanciranje od onoga što se kazuje, kao i na upotrebu senta, scusi/senti, scusa za privlačenje pažnje nepoznatog sagovornika, kroz zadatak sa postavljanjem pitanja prema ponuđenom primeru (ibid., 46), s tim da iste forme u ovoj funkciji nalazimo i u Un giorno in Italia 1 (Chiappini \& De Filippo, 2002: 142), u zadatku sa sastavljanjem rečenica od ponuđenih delova i navedenih izraza, kao i u Contatto 1 (Bozzone Costa, Ghezzi et al., 2005: 34), u tabeli sa prikazom raznih funkcija.

Veoma učestalo se, zapravo, u udžbenicima skreće pažnja na funkciju privlačenja sagovornikove pažnje u kojoj se javlja i forma ehi (Cozzi, Federico et al., 2005: 91), kao i na funkciju zahtevanja potvrde, u čijoj se službi mogu javiti eh (Cozzi, Federico et al., 2005: 91), ..., no? (De Savorgnani \& 
Cordera Alberti, 2012: 93), ..., vero? (De Savorgnani \& Cordera Alberti, 2012: 93; Bozzone Costa, Ghezzi et al., 2005: 34), ..., giusto? (Bozzone Costa, Ghezzi et al., 2005: 34). Zabeležili smo i izolovan slučaj isticanja, u okviru odeljka posvećenog leksici, funkcije pregovaranja i uveravanja koju mogu vršiti va be', comunque, secondo me (Guastalla \& Naddeo, 2011: 121, 204), kao i funkcije prekidanja i preuzimanja reči pomoću scusi se La interrompo, volevo dire, certo/mi scusi i ma, Le chiedo scusa (Errico, Esposito et al., 2008: 132). Ili slučaj skretanja pažnje na sai, veramente, mah, davvero?, senti i scusa, certo koji iščezavaju prilikom prebacivanja u indirektan govor rečenica iz direktnog govora koje ih sadrže (Gruppo Meta, 1993: 185). Ne izostaju, međutim, ni slučajevi navođenja učenika na upotrebu izvesnih formi prema ponuđenim primerima, ali bez preciziranja funkcije koju one vrše u datom kontekstu, npr. eh sì (Marimi \& Vicentini, 1998: 106), scusa, allora (Bozzone Costa, Ghezzi et al., 2005: 77, 81), cioè, infatti, insomma, i dr. (Cozzi, Federico et al., 2006: 141). Ili, s druge strane, jasno ukazivanje na funkciju, npr. „,dobijanje na vremenu za razmišljanje" i njeno spajanje s odgovarajućom formom, kakva je inicijalna allora, ali bez metalingvističkih objašnjenja o samoj funkcionalnoj kategoriji (Mezzadri \& Balboni, 2000: 106).

\section{Analiza materijala: eksplicitni fokus}

Tek se u neznatnom broju udžbenika DM eksplicitno tretiraju, a nadalje ćemo opisati način (aktivnosti, tehnike) na koji je to učinjeno. Prema našim saznanjima, to su (hronološkim redosledom): Tra dire e fare (Borgarelli Bacoccoli, 1996), Rete! 3 (Mezzadri \& Balboni, 2002), Viaggio nell'italiano (Bozzone Costa, 2004), UniversItalia (Piotti \& De Savorgnani, 2006), Contatto 2B (Ghezzi, Piantoni et al., 2009), Uni.Italia (Fragai, Fratter et al., 2010), Magari (De Giuli, Guastalla et al., 2008) i njegove novije verzije - Nuovo Magari (B2), (C1/C2) (De Giuli, Guastalla et al., 2013a/b), Nuovo Contatto C1 (Bozzone Costa, Piantoni et al., 2013), L'italiano all'università 2 (La Grassa, Delitala et al., 2013), Parla con me (Anzivino, D’Angelo et al., 2013).

Prvi od takvih udžbenika koji smo otkrili, a u kom se ukratko predočavaju DM u prilogu sa gramatikom, jeste Borgarelli Bacoccoli (1996: 395), gde je navedeno da se uzvici, kao i druge vrste reči, mogu upotrebiti u svojstvu DM i popisane su 34 forme zajedno sa jednom ili više funkcija 
koje obavljaju (npr. allora za otpočinjanje ili okončanje reči, anzi za autokorekciju, appunto za potvrđivanje), uz dodatnu napomenu da se uzvici poput vero, cioè, capito?, a questo punto, no? mogu koristiti i kao ispunjivači ili poštapalice, lišeni bilo kakvog određenog značenja.

U Mezzadri i Balboni (2002: 11), kroz aktivnost s čitanjem u 1. lekciji, uz sažeto objašnjenje o njihovoj ulozi u komunikaciji, ponuđeno je 6 funkcionalnih kategorija i odgovarajućih izraza, nazvanih „marcatori del discorso orale": dobijanje na vremenu (dunque, allora, dove eravamo), naglašavanje ili modifikovanje rečenog (in realtà, a dire la verità, comunque), zahtevanje pažnje (guarda/i/ate, ascolta/i/ate, aspetta/i/ate un momento, senta scusi), skretanje toka neprijatnog ili ugrožavajućeg razgovora (in realtà il problema è un altro, bisogna considerare anche...), umanjenje jačine određene tvrdnje (secondo me, credo di poter dire che, a mio avviso, mi sembra che), objašnjavanje i potvrđivanje (cioè, infatti, ad esempio, praticamente, in altre parole, volevo dire), a od učenika se očekuje da ih pročita i razmisli o tome da li je sa svima upoznat. Pretpostavljamo i da se očekuje da će u aktivnostima za usmenu i pisanu produkciju koje neposredno slede učenik upotrebiti ove izraze, premda tako nešto nije naznačeno.

Bozzone Costa (2004: 34) u sintezi gramatičkih sadržaja, u 1. lekciji, ukazuje na marker guarda za zahtevanje pažnje i navodi da se u analognoj funkciji mogu naći i senti/a, senti un po', mi segui, dimmi, di' (un po'), dica, vedi/a, dok su u jednoj od potonjih lekcija u fokusu ecco, za otpočinjanje razgovora zajedno sa dunque, ora, allora, kao i marker diciamo za mitigaciju, naporedo sa per cosi dire, come dire, in qualche modo, in un certo senso (ibid., 142). Nisu zapostavljene ni druge forme ni funkcije, npr. allora i ecco u 2. lekciji (ibid.,53), gde učenik treba ne samo da zaključi koju funkciju vrši istaknuta forma u navedenom primeru iz slušanja, već i da je samostalno definiše, a slični zahtevi za odgonetanjem funkcije markera upućeni su mu i u potonjim lekcijama, npr. u vezi sa tra virgolette (ibid., 200) i bene (ibid., 277), kao i sa čitavim nizom markera, poput proprio, appunto, secondo me, come ti dicevo prima i drugih, navedenih u zadatku sa tehnikom cloze (ibid., 314-315). Nešto obimniji skup funkcija konektora i DM naveden je u odeljku o tekstualnoj koheziji, u zadatku (ibid., 200) u kome treba povezati navedene funkcije: otvaranje razgovora i izvođenje zaključaka, pojačavanje i potvrđivanje rečenog, objašnjavanje i preciziranje, nabrajanje i suprotstavljanje argumenata, nastavljanje započetog govora, sa odgovarajućim primerima ekscerpiranim iz prethodne ak- 
DIDAKTIČKI MATERIJALI ZA ITALIJANSKI KAO L2...

tivnosti sa slušanjem, u kojima su podvučene forme: dicevo, cioè, dunque, eh beh, da una parte. U istom odeljku (ibid., 201) nalazi se i zadatak sa dopunjavanjem formi sadržanih u slušanju na odgovarajući prazan prostor pokraj opisa tri različite funkcije (dodavanje informacija, fokalizacija, egzemplifikacija), kao i sa navođenjem, uz pomoć nastavnika, drugih, ekvivalentnih markera i konektora koji se mogu naći u svakoj od funkcija. Sem toga, u pregledu najvažnijih gramatičkih partija u zaključnom delu udžbenika (ibid., 498-500), sadržan je iscrpan opis markera tipičnih za razgovorni jezik i predočena je njihova podela na osnovu interakcionih (od strane (sa)govornika) i metatekstualnih funkcija.

U Piotti i De Savorgnani (2006: 178-179) DM su predmet gramatičkih pouka u lekciji namenjenoj nivou B1. U pitanju je aktivnost iz dva dela: prvi se sastoji u dopunjavanju odlomka iz intervjua koji su učenici prvobitno imali prilike da čuju, markerima innanzi tutto, dunque, sia... sia/che, in secondo luogo, non solo ma anche, prima di tutto, cioè, dok se drugi deo aktivnosti sastoji u ubacivanju navedenih formi pokraj opisa funkcije koje one vrše u tekstu, npr. započinjanje diskursa, uvođenje najvažnije informacije, preciziranje ili objašnjavanje.

Ghezzi, Piantoni et al. (2009) među sadržajima koji se tiču veština i funkcija, u gotovo svakoj lekciji za nivo B2 imaju zastupljene DM. U pitanju su: aktivnost sa svrstavanjem formi sadržanih u slušanju prema dvema funkcijama - otpočinjanje govorenja i vraćanje na temu (ibid., 4), beleženje izraza iz slušanja kojima se izražavaju neslaganje/neverica i delimično slaganje, kao i upotreba tih izraza (ma come è possibile..., sì, è vero... ma questo non vuol dire...) pri konstruisanju mini-dijaloga po navedenom uzoru (ibid., 22), navođenje formi iz cloze vežbe koje iskazuju sumnju, neslaganje, zaključak (ibid., 41-42), povezivanje niza formi istaknutih u rečenicama iz slušanja sa njihovim funkcijama, recimo, no? za traženje potvrde ili non lo so za dobijanje na vremenu pre otpočinjanja kazivanja i dr. (ibid., 63), vežba s dopunjavanjem oblicima koji kazuju sumnju i neslaganje, a o čijoj funkciji učenik treba da razmisli uz pomoć nastavnika (ibid., 80).

Fragai, Fratter et al. (2010) među tekstualnim sadržajima za ciljni nivo B1-B2, sledeći Bazzanellinu funkcionalnu klasifikaciju, sistematično prezentuju: fatičke markere i ispunjivače come sapete, eeh praticamente, capite no?, diciamo (ibid., 23), markere u službi ustupanja reči, kontrole prijema i zahtevanja objašnjenja prego, è chiaro?, no?, eh?, e cioè? (ibid., 55), markere parafraze, korekcije i egzemplifikacije cioè, ovvero, diciamo, 
per esempio (ibid., 167), i to kroz istovetan tip aktivnosti sa označavanjem koju od datih funkcija obavljaju forme istaknute u transkribovanim rečenicama iz slušanja. Prezentuju se i fokalizatori, pozivanjem studenta na refleksiju o mogućnosti njihove eliminacije i na odabir jedne od dve ponuđene, alternativne forme u rečenicama (ibid., 120); zatim markeri prezentacije, upućivanja i zatvaranja, dopunjavanjem odgovarajućim formama iz slušanja (ibid., 184); kao i modulatori, preciziranjem da li istaknute forme vrše funkciju pojačavanja ili umanjivanja snage onoga što je rečeno (ibid., 231). Sem toga, dat je i detaljan opis svake od pomenutih funkcija na kraju udžbenika, u tabelarnom pregledu tekstualnih sadržaja (ibid., 269-270).

De Giuli, Guastalla et al. (2008: 63-65) u lekciji za ciljni nivo B1, ${ }^{6} \mathrm{u}$ odeljku o analizi konverzacije, upoznaju učenika sa markerima come dire, insomma, ah, e dunque, diciamo, cioè, no?, voglio dire, beh, ecco, sai i njihovim raznim funkcijama, od otvaranja/zatvaranja diskursa, ispunjavanja pauze, do traženja i davanja potvrde ili do reformulacije i dr. U aktivnosti se od učenika očekuje da pomenute forme izdvoji iz intervjua koji sluša i zabeleži ih, zatim da odabrane oblike upiše na odgovarajuće prazno mesto u transkribovanim rečenicama iz intervjua (komplementaciona tehnika), a potom i da svaku od rečenica poveže sa deskripcijom funkcije koju data forma u njoj vrši (kombinaciona tehnika), npr. reformulacija putem cioè. U narednoj aktivnosti ludičkog karaktera, u improvizaciji dijaloga s argumentacijom suprotstavljeni parovi učenika treba da ispravno upotrebe što je veći broj ovih formi u ograničenom vremenskom roku.

U lekcijama namenjenim nivou B2 (De Giuli, Guastalla et al., 2008: 99), takođe u odeljku o analizi konverzacije predočavaju se najpre ,formule“ za dobijanje na vremenu i prekidanje kroz aktivnost sačinjenu iz tri dela: 1. slušajući intervju učenik treba da naznači kakvim izrazom započinju replike sagovornika tj. onim za dobijanje na vremenu, za prekidanje ili dr.; 2. izraze upotrebljene u slušanju (allora, beh, scusa(mi)) treba da razvrsta u tabeli prema funkciji koju obavljaju (dobijanje na vremenu ili signaliziranje započinjanja govora i prekidanje); 3. tabelu treba da dopuni drugim, ponuđenim izrazima (mah, dunque, eh no, va bene zajedno sa ho capito, ma, sai/sa, si però, vediamo) u skladu sa dvema odgovarajućim funkcijama. Sledi (ibid., 100) role-play s instrukcijama prema kojima jedan učenik preuzima ulogu osobe refleksivnog karaktera, koja upotreblja-

6 Up. noviju verziju udžbenika, De Giuli, Guastalla et al. (2013a: 55-57), gde su aktivnosti nepromenjene, ali je nivo pripadanja lekcije modifikovan u B2. 
va izraze za dobijanje na vremenu i signaliziranje početka govora kako bi smireno odgovarala na pitanja, dok ga drugi, nestrpljiv i u žurbi, neprestano prekida i požuruje u davanju odgovora, koristeći raspoloživa jezička sredstva radi ostvarenja svog cilja. Istom nivou kompetencije namenjena je zatim i aktivnost sa DM ah, magari, oltretutto, guarda, meno male, non un gran che, sadržanim u replikama učesnika intervjua i koje učenik najpre treba da rasporedi na odgovarajuće mesto u transkriptu, a zatim i da pripiše datom opisu funkcije, npr. signaliziranje razumevanja ili iznenađenja povodom sagovornikove tvrdnje, nakon čega sledi i aktivnost sa dramatizacijom datog intervjua (De Giuli, Guastalla et al., 2008: 160; up. 2013b: 58, ista aktivnost u lekciji koja pripada nivou C1).

U lekcijama namenjenim C1 nivou DM se, međutim, ne pominju kao takvi, ali se određena pažnja poklanja npr. funkciji ma za uvođenje nove teme (De Giuli, Guastalla et al., 2008: 209; up. 2013b: 82), kao i refleksiji o verbalnim tikovima sa formama poput piuttosto che, come dire, praticamente, insomma, eccetera eccetera (De Giuli, Guastalla et al., 2008: 209; up. 2013b: 117, u lekciji za C2 nivo), što smatramo indirektnim načinom ukazivanja na idiosinkratičku funkciju markera.

Nivou C1 namenjen je i Bozzone Costa, Piantoni et al. (2013: 59), gde se u odeljku o tekstualnosti učeniku nudi da na osnovu intervjua koji je prethodno slušao popuni cloze markerima: se vogliamo, diciamo, dunque, tanto per dire, direi, dicevo prima, ebbene, a zatim i da ih klasifikuje prema ponuđenim funkcijama (ublažavanje snage onoga što je rečeno, navođenje primera, povezivanje sa prethodno rečenim, nastavljanje započetog i završetak izlaganja). Slična vežba nalazi se u jednoj od narednih lekcija (ibid., 115) sa addirittura, cioè, però non so, sai, così, guarda, un po' i još nekim funkcijama (npr. reformulisanje, uspostavljanje kontakta, preuzimanje reči), pri čemu se posebna pažnja skreće na višestruke forme i funkcije markera vabbe'. Dopunjavanje, odnosno cloze je učestao tip aktivnosti u ovom udžbeniku, namenjen upotrebi DM kao što su si/capisco zajedno sa però, mi scusi, ecco, quindi, giusto, se lo lasci dire, magari (ibid., 187), diciamo, solo che, capisce che, bene zajedno sa ma, e sa allora (ibid., 62), a novina u ovakvim aktivnostima jeste da su u određenim slučajevima (ibid., 163, 215) učeniku ponuđene ne samo forma već i funkcija koju dati marker vrši u kontekstu (npr. ecco za započinjanje razgovora ili no? za zahtevanje slaganja, i dr.). Sem toga, u sintezi gramatičkih sadržaja na kraju knjige predočena je i nizom primera ilustrovana, funkcionalna klasifikacija interakcionih i metatekstualnih DM (ibid., 144-145). 
La Grassa, Delitala et al. (2013) poseban odeljak posvećuju tekstualnim elementima, neophodnim za zadovoljenje osobenih jezičkih potreba akademske publike, gde se uz konektore, u više navrata tj. lekcija obrađuju i DM, i to brojne njihove forme: allora, ecco, certo, vedi za uzimanje reči i zahtevanje pažnje (ibid., 74), kao i senta, guardi, scusa takođe za zahtevanje pažnje, ali i prego, sì u kombinaciji sa dimmi za ustupanje reči (ibid., 103), te drugi markeri kao voglio dire, passiamo ad altro, torniamo a (ibid., 175), veramente, beh, dai, pure (ibid., 193). Primera radi, nakon rečenica iz prethodno navedenog pisanog teksta u kojima su istaknuti DM i sažetog objašnjenja da su u pitanju izrazi tipični za razgovorni jezik, studentu se nalaže da navede forme koje ispunjavaju određene funkcije, kao što su npr. zahtevanje pažnje, pozivanje na ono što je upravo izrečeno, objašnjavanje (ibid., 74).

U Anzivino, D'Angelo et al. (2013: 45) markeri senta/senti, guardi/ guarda uvršteni su u odeljak o gramatičkoj analizi, gde nakon što pročita transkript odlomka dijaloga iz prethodne aktivnosti sa slušanjem, učenik treba da odabere jedno od po tri ponuđena objašnjenja uloge guardi koji se javlja u slušanju, bilo da je u pitanju, s jedne strane, njegova striktno gramatička funkcija (imperativ u formalnom obraćanju) ili s druge, skretanje pažnje na informacije koje će uslediti. Nakon toga usleđuje kratko, eksplicitno objašnjenje ove funkcije zajedno s primerima dijaloških razmena u kojima su upotrebljeni ovi markeri.

Sem pomenutih udžbenika, DM su i predmet eksplicitnog bavljenja u nekolicini specijalizovanih priručnika, ${ }^{7}$ među kojima se naročito izdvaja Zamora, Arianna et al. (2006), gde uz frazeologizme oni zauzimaju prioritetno mesto i jedno obimnije poglavlje. Izdvojili bismo i Brighetti i Minuz (2001), gde se nude predlozi za promišljanje nastavnika o važnim aspektima veštine govorne produkcije, ali i za konkretne aktivnosti koje se mogu sprovesti u učionici (preuzete iz nekolicine udžbenika nastalih u periodu od 1985. do 1997. godine), vezano npr. za mehanizme razmene reči (ibid., 29-40). Napomenimo još i da Riggenbach (1999) nudi niz komunikativnih didaktičkih aktivnosti, primenjivih ne samo na engleski, u kojima učenik preuzima ulogu konverzacionog analitičara i fokusira se na mehanizme uzimanja reči, ispunjivače, popravke, propratne markere i dr.

7 Ne možemo, međutim, a da ne primetimo da Luraghi i Venier (2009), u svom sažetom, praktičnom priručniku koji ima za cilj da premosti jaz između pažnje koja se na univerzitetskim kursevima o opštoj lingvistici s jedne strane poklanja fonetici, fonologiji, morfologiji i sintaksi, a s druge strane uskraćuje pragmatici i tekstualnoj lingvistici, čak i semantici, ne nalaze za shodno da posvete nijedno vežbanje DM. 


\section{Diskusija}

Uprkos svemu, mišljenja smo (up. Jones \& Carter, 2014; Cullen \& Kuo, 2007; Hellermann \& Vergun, 2007) da je u navedenim, malobrojnim didaktičkim materijalima pruženo premalo prostora DM. Naime, u svega $10 \%$ analiziranih udžbenika DM se eksplicitno tretiraju. ${ }^{8}$ Premda se u približno istom broju udžbenika (11) u kojima se markeri izričito obrađuju, javljaju i oni (12) u kojima se markeri ne predočavaju na transparentan način, smatramo da je sveukupan broj ovih udžbenika ipak nedovoljan. Zapazili smo da gotovo svi udžbenici koji eksplicitno posvećuju pažnju markerima, isto čine i sa konektorima (izuzetak su Mezzadri \& Balboni, 2002 i De Giuli, Guastalla et al., 2013a/b, premda se i oni, iako neeksplicitno, bave konektorima), ali ne i obrnuto: broj udžbenika koji u našoj analizi tretiraju konektore gotovo dva i po puta veći je od onih koji se bave DM (26 prema 11).

Svih 11 udžbenika s jasnim fokusom na markere namenjeno je intermedijalnom i naprednom nivou kompetencije tj. od B1 naviše, i to odrasloj populaciji, s izuzetkom Anzivino, D’Angelo et al. (2013), koji je namenjen omladini. Činjenica da među ovih 11 udžbenika nema, dakle, nijednog namenjenog početnom nivou kompetencije vrlo verovatno ukazuje na mišljenje autora da podučavanje treba rezervisati tek za naprednije nivoe što ne odgovara stavu koji mi zastupamo, imajući između ostalog u vidu i da su DM kategorija koja se javlja već u ranim fazama usvajanja (Ceković, 2014, 2016).

U navedenim udžbenicima primetno je da se DM predočavaju u međusobno različitim odeljcima, uglavnom posvećenim gramatici ili tekstualnosti tj. tekstualnoj koheziji (uključujući neretko i sintetički pregled ovih sadržaja na kraju knjige), ali i veštinama i funkcijama, pa čak i analizi konverzacije, što svakako ukazuje na različite ciljeve i prioritete udžbenika unutar komunikativnog pristupa za koji su svi opredeljeni, ali i da ne postoji uniforman način svrstavanja i prezentovanja ovih elemenata, barem ne onako kao što je to tradicionalno u udžbenicima slučaj sa gramatičkom, leksičkom i drugom građom.

Primetna je tendencija, izražena kod približno jedne polovine udžbenika, da posvećuju obimnu pažnju DM, čineći to u većem broju lekcija i

8 Prilikom računanja ćemo umesto Magari (De Giuli, Guastalla et al., 2008) uzeti u obzir samo nova izdanja ovog udžbenika, Nuovo Magari (De Giuli, Guastalla et al., 2013a/b). 
kroz niz aktivnosti (takvi su: Bozzone Costa, 2004; Bozzone Costa, Piantoni et al., 2013; Ghezzi, Piantoni et al., 2009; Fragai, Fratter et al., 2010; La Grassa, Delitala et al., 2013), odnosno kod druge polovine, da sadrže markere najčešće u samo jednoj lekciji i u svega jednoj ili dve vežbe (u Borgarelli Baccocoli, 1996, a može se reći i u Mezzadri \& Balboni, 2002, aktivnosti čak izostaju, što ne čudi ako se uzme da su u pitanju pionirski didaktički koraci na ovom polju).

Tipologija zastupljenih aktivnosti u vezi sa DM je raznovrsna. Vrlo često im prethodi aktivnost namenjena razvoju veštine razumevanja slušanog, (polu)autentičnog teksta, ${ }^{9}$ iz kojeg zatim, pri ponovljenom slušanju, učenik izdvaja tražene forme i funkcije markera. S druge strane, aktivnosti sa DM neretko služe kao uvod u role-play ili dramatizaciju, kao narednu aktivnost u kojoj se od učenika očekuje da primeni markere na koje je fokusiran. Evidentno je, stoga, da prilikom prezentovanja ove građe udžbenici prate tradicionalni PPP okvir, Prezentacija - Praksa - Produkcija (up., npr. McCarthy \& Carter, 1995): učeniku se najpre prezentuju ciljne forme i funkcije, zatim mu se daje prilika za njihovo uvežbavanje u učionici tj. u kontrolisanom okruženju, a potom i prilika za produkciju, u okviru koje se očekuje da će ih spontano upotrebiti na adekvatan način.

Najučestaliji tip aktivnosti jeste dopunjavanje, odnosno cloze, ali i povezivanje, kao i odabir jednog od više ponuđenih rešenja, a suština ovih aktivnosti sastoji se u dovođenju u vezu određenih formi i funkcija markera. Takvo spajanje (kombinovanje, pridruživanje, matching) se go-

9 Pitanje autentičnosti tekstova, nepresušan izvor diskusija u didaktičkim vodama, postaje naročito bitno kad je reč o DM kojima obiluje spontani razgovorni jezik. Spontanost dijaloga u direktnoj je vezi sa prisustvom DM, naročito onih u interakcionim funkcijama. Stoga su, prilikom kreiranja nastavnih materijala, jedan od prioriteta odabir i ponuda valjanih uzoraka diskursa. Širu raspravu o tome ostavićemo, međutim, za neku narednu priliku (za detalje v. npr. Long, 2007 ili Gillani \& Pernas, 2013). Napomenimo samo da Tateyama, Kasper et al. (1997: 164) navode kako je poređenje autentičnih konverzacija iz učionice (za koje je tipičan, tradicionalni obrazac: inicijacija - respons - feed-back) i načina predstavljanja govornih razmena u nastavnim materijalima pokazalo da su udžbenici u tom smislu često defektni (što je naročito vidljivo u pogledu zatvaranja konverzacije i upravljanja njenom strukturom), te da upravo takav kvalitativno i kvantitativno neadekvantan pragmatički input, uz ograničenu produktivnost i nedovoljnu kontekstualnu raznovrsnost upotrebe jezika, otežava učenicima usvajanje pragmatičkih fenomena ukoliko se ono isključivo ili dominantno odvija u instrukcionim uslovima tj. u kontekstu Ls. 
tovo uvek odvija tako što su učeniku ponuđene i forme i funkcije, bilo da je u pitanju ubacivanje ponuđenih formi pokraj opisa funkcije koje one vrše u datom kontekstu ili povezivanje niza formi istaknutih u rečenicama ekscerpiranim iz slušanja sa definicijama njihovih funkcija, ili prosto odabiranje jedne od ponuđenih funkcija koje data forma vrši. Na taj način potpomaže se fokusiranje učenikove pažnje na funkcionalnost ovih elemenata u diskursu. Učenik se često i eksplicitno poziva na refleksiju o markerima, sticanje svesti o njihovim mnogostrukim oblicima i ulogama, ali i odgonetanje funkcija u datom kontekstu, ukoliko je potrebno i uz pomoć nastavnika. Vrlo retko se od učenika traži i da samostalno definiše određene funkcije markera. Ovim putem se kod njega aktiviraju procesi dedukcije i inferencije, koji podstiču usvajanje i memorisanje naučenog u dužem vremenskom roku. Pa ipak, premda raznovrsne, a zastupljene su kako prezentacione, tako i one analitičke i produktivne, takve aktivnosti po našem mišljenju, čak i u udžbenicima koji posvećuju dosta prostora DM pružene su u nevelikom broju i obimu (up., npr. Ghezzi, Piantoni et al., 2009; Fragai, Fratter et al., 2010).

Kod svih autora prezentovan je, međutim, širok dijapazon brojnih formi i funkcija (uz skretanje pažnje i na analogne oblike), na osnovu čega zaključujemo da autori prepoznaju važnost isticanja polifunkcionalnosti kao bitnog obeležja DM. Među najučestalije prezentovanim formama su: cioè, dunque, guarda/i, senti/a, allora, diciamo, no?, ecco, scusa/i (Bozzone Costa, Piantoni et al., 2013 i De Giuli, Guastalla et al., 2008 ističu se, recimo, po tome što se bave i nekim od ređe navođenih formi). Među funkcijama najčešće se javljaju: uzimanje, zadržavanje i ustupanje reči, zahtevanje pažnje, egzemplifikacija, modulacija i dr. Ipak, u izvesnim slučajevima nalazimo da su ponuđena objašnjenja funkcija prilično štura i neprecizna (up., npr. La Grassa, Delitala et al., 2013: 74; De Giuli, Guastalla et al., 2008: 160, gde se u kontekstu funkcija koje određeni izrazi vrše, npr. ah za signaliziranje razumevanja ili za izražavanje iznenađenosti, stoji i da meno male i un gran che imaju ulogu sinonima za per fortuna i bruttino, premda bi se takva njihova uloga radije mogla pripisati modulaciji).

Među udžbenicima fokusiranim na DM, zapažamo da je u čak tri takva slučaja jedan od (ko)autora ista osoba (Bozzone Costa, 2004; Bozzone Costa, Piantoni et al., 2013; Ghezzi, Piantoni et al., 2009), što ukazuje na tendenciju ovog autora da, sarađujući na izradi različitih udžbenika, sledi isti obrazac koji 
uključuje DM. Štaviše, upravo se ova 3 udžbenika, zajedno sa Fragai, Fratter et al. (2010) ističu po količini pažnje (kvantitativnoj i kvalitativnoj) koja je poklonjena DM, što generalno ukazuje na ograničen, mali broj italijanskih autora koji pridaju značaj markerima i sistematično ih uključuju u materijale.

\section{Zaključak}

Analizom zastupljenosti DM u udžbenicima došli smo, napokon, i do otkrića koje smatramo indikativnim u pogledu značaja Zajedničkog evropskog okvira (Council of Europe, 2001), kao dokumenta koji im pridaje određenu važnost (up. Ceković, 2016: § 3.2.). Zapazili smo, naime, da su svi udžbenici s fokusom na DM novijeg datuma: velika većina nastala je, zapravo, u poslednjoj deceniji, a ako izuzmemo pionirski poduhvat Borgarelli Bacoccoli (1996), u kome su sadržana isključivo teorijska objašnjenja o tome šta su DM, ali ne i aktivnosti za njihovo uvežbavanje, svi ostali udžbenici datiraju iz perioda nakon objavljivanja Okvira. Uviđamo, dakle, da tek u udžbenicima za učenje italijanskog kao L2 objavljenim nakon 2001. godine, prisustvo DM postaje eksplicitno. Do tog datuma, kako smo istakli, DM se ne izdvajaju kao kategorija, niti se pruža njihov fukcionalni opis, već se samo latentno inkorporiraju u sadržaj didaktičkih jedinica. Zaključujemo, stoga, da je svojim sadržajem i svojom difuzijom Okvir odigrao jednu od ključnih uloga u doprinošenju prodiranja DM i u udžbenike, ali da je njihovo prisustvo i dalje sporadično i nedovoljno.

\section{Literatura}

Bardovi-Harlig, K., Hartford, B. A. S, Mahan-Taylor, R., Morgan, M. J. \& Reynolds, D. W. (1991). Developing pragmatic awareness: closing the conversation. ELT Journal, 45 (1), 4-15.

Bazzanella, C. (1995). I segnali discorsivi. In L. Renzi, G. Salvi \& A. Cardinaletti (eds.), Grande grammatica italiana di consultazione, vol. 3 (pp. 225-257). Bologna: Il Mulino.

Bazzanella, C. (2008). Linguistica e pragmatica del linguaggio. Un'introduzione. Roma-Bari: Gius. Laterza \& Figli.

Ceković-Rakonjac, N. (2011). Različiti pristupi definisanju i opisu diskursnih markera. Anali Filološkog fakulteta, 23 (2), 133-153. 
Ceković, N. (2014). I segnali discorsivi nell'interlingua degli studenti universitari di italiano L2. Italica Belgradensia, 2, 93-110.

Ceković, N. (2016). Diskursni markeri u govornoj produkciji na italijanskom kao drugom jeziku (neobjavljena doktorska disertacija). Filološki fakultet, Beograd.

Ceković, N. \& Janićijević, N. (2017). Scusa, sai, ti dico... Gli equivalenti serbi dei segnali discorsivi italiani di origine verbale. Anali Filološkog fakulteta, 29 (2), 51-65.

Ceković, N. \& Radojević, D. (2016). Polifunkcionalnost italijanskih diskursnih markera u prevođenju na srpski. In A. Vraneš \& Lj. Marković (eds.), Kulture u prevodu, vol. 2 (pp. 233-246). Beograd: Filološki fakultet.

Council of Europe (2001). Common European Framework of Reference for Languages: Learning, teaching, assessment. Cambridge: Cambridge University Press.

Cullen, R. \& Kuo, I. (2007). Spoken Grammar and ELT Course Materials: A Missing Link? TESOL Quarterly, 41 (2), 361-386.

Fung, L. \& Carter, R. (2007). Discourse Markers and Spoken English: Native and Learner Use in Pedagogic Settings. Applied Linguistics, 28 (3), 410-439.

Gillani, E. \& Pernas, P. (2013). Input orale e competenza dialogica: le scelte dei manuali di italiano LS. Studi Italiani di Linguistica Teorica e Applicata, 42 (1), 61-99.

Hellermann, J. \& Vergun, A. (2007). Language which is not taught: The discourse marker use of beginning adult learners of English. Journal of Pragmatics, 39, 157-179.

House, J. (2013). Developing pragmatic competence in English as a lingua franca: Using discourse markers to express (inter)subjectivity and connectivity. Journal of Pragmatics, 59, 57-67.

Imazu, M. \& Valeri, L. (2004). Lo sviluppo della sintassi in italiano L2. Input didattico e abilità di produzione scritta. Siena: Università per Stranieri di Siena.

Jones, C. \& Carter, R. (2014). Teaching spoken discourse markers explicitly: A comparison of III and PPP. International Journal of English Studies, 14 (1), 37-54.

Long, M. H. (ed.) (2007). Problems in SLA. Mahwah, NJ: Lawrence Erlbaum.

McCarthy, M. \& Carter, R. (1995). Spoken grammar: what is it and how can we teach it? ELT Journal, 49 (3), 207-218.

Moderc, S. (2015). Su un modo di tradurre l'avverbio serbo "inače" in italiano: il caso dell'equivalente "altrimenti”. Italica Belgradensia, 2015 (1), 61-79.

Müller, S. (2005). Discourse Markers in Native and Non-native English Discourse. Amsterdam/Philadelphia: John Benjamins.

Pernas, P., Gillani, E. \& Cacchione, A. (2011). Costruire testi, strutturare conversazioni: la didattica dei segnali discorsivi come elementi pivot nell'interazione verbale. Italiano LinguaDue, 1, 65-138.

Tateyama, Y., Kasper, G., Mui, L. P., Tay, H.-M. \& Thananart, O. (1997). Explicit and implicit teaching of pragmatic routines. In L. F. Bounton (ed.), 
Pragmatics and Language Learning, vol. 8 (pp. 163-177). Urbana, Illinois: University of Illinois.

\section{Izvori}

Amati, D. \& Bacci, P. (1999). Un tuffo nell'azzurro, corso di italiano per stranieri 1. Rimini: Panozzo.

Amati, D. \& Bacci, P. (2002). Un volo nell'azzurro, corso di italiano per stranieri 2. Rimini: Panozzo.

Anzivino, F., D’Angelo, K. \& Pedol, D. (2013). Parla con me 3. Corso di lingua e cultura italiana per ragazzi (B1 juniores). Firenze: Alma.

Azzarà, V., Scarpocchi, R. \& Vicenti, F. (1996). Viaggio in Italia. Testo di civiltà e cultura italiana per stranieri. Livello intermedio e avanzato. Perugia: Guerra.

Bailini, S. \& Consonno, S. (2002). Ricette per parlare: attività e giochi per la produzione orale. Firenze: Alma.

Balì, M. \& Rizzo, G. (2002). Espresso 2. Corso di italiano. Libro dello studente ed esercizi. Firenze: Alma.

Balì, M. \& Rizzo, G. (2003). Espresso 3. Corso di italiano. Libro dello studente ed esercizi. Firenze: Alma.

Balì, M. \& Rizzo, G. (2014). Nuovo Espresso 2: corso di italiano (A2). Libro dello studente e esercizi. Firenze: Alma.

Balì, M. \& Ziglio, L. (2015). Nuovo Espresso 3: corso di italiano (B1). Libro dello studente e esercizi. Firenze: Alma.

Bettinelli, B., Della Putta, P. \& Visigalli, M. (2011). Buona idea! Corso di lingua e cultura italiana. Livello elementare. Milano/Torino: Pearson.

Bettoni, C. \& Vicentini, G. (1997). Passeggiate italiane. Lezioni di italiano, livello avanzato. Roma: Bonacci.

Blatešić, A. (2007). Amici 1. Italijanski jezik za peti razred osnovne škole. Prva godina učenja. Beograd: Zavod za udžbenike.

Blatešić, A. \& Stojković, J. (2008). Amici 2. Italijanski jezik za šesti razred osnovne škole. Druga godina učenja. Beograd: Zavod za udžbenike.

Blatešić, A. \& Stojković, J. \& Zavišin, K. (2011). Amici 3. Italijanski jezik za sedmi razred osnovne škole. Treća godina učenja. Beograd: Zavod za udžbenike.

Borgarelli Bacoccoli, A. (1996). Tra dire e fare. Corso di lingua italiana. Livello medio/avanzato. Perugia: Guerra.

Bozzone Costa, R. (2004). Viaggio nell'italiano. Corso di lingua e cultura italiana per stranieri (B1/C1). Torino: Loescher.

Bozzone Costa, R., Ghezzi, C. \& Piantoni, M. (2005). Contatto 1. Corso di italiano per stranieri. Livello principiante - elementare (A1/A2). Torino: Loescher.

Bozzone Costa, R., Piantoni, M., Scaramelli, E. \& Ghezzi, C. (2013). Nuovo Contatto C1. Corso di lingua e civiltà italiana per stranieri. Torino: Loescher. 
Brighetti, C. \& Minuz, F. (2001). Abilità del parlato. Torino: Paravia.

Cammarota, G. (ed.) (1999). Parlando italiano 1. Libro di testo. Corso multimediale di lingua e cultura italiana. Perugia: Guerra.

Cammarota, G., Fasoglio, D., Prando, L., Boriosi-Katerinov, M. C., Katerinov, K., Pichiassi, M., Carrera Diaz, M. \& Rodriguez Renia, P. (2000). Parlando italiano 2. Libro di testo. Perugia: Guerra.

Caon, J., Ceccon, W., De Gerone, M., Dordi, C., Piaia, M., Primucci, R., Raffaelli, T., Vaccarin, R. (2011). In bocca al lupo, ragazzi! 1 Corso di italiano per la scuola secondaria di primo grado (11-14 anni), libro dello studente. Firenze: Alma.

Chiappini, L. \& De Filippo, N. (2002). Un giorno in Italia. Corso di italiano per stranieri (primo livello). Roma: Bonacci.

Chiappini, L. \& De Filippo, N. (2005). Un giorno in Italia 2. Corso di italiano per stranieri (intermedio avanzato). Roma: Bonacci.

Chiuchiù, A., Minciarelli, F. \& Silvestrini, M. (1990). In italiano. Corso multimediale di lingua e civiltà italiana a livello elementare e avanzato. Perugia: Guerra.

Conforti, C. \& Cusimano, L. (1997). Linea diretta 1. Corso di italiano per principianti. Perugia: Guerra.

Conforti, C. \& Cusimano, L. (2003). Linea diretta 2. Corso di italiano a livello medio. Perugia: Guerra.

Cozzi, N., Federico, F. \& Tancorre, A. (2005). Caffè Italia 1. Corso di italiano. Libro dello studente con esercizi. Recanati: ELI.

Cozzi, N., Federico, F. \& Tancorre, A. (2006). Caffè Italia 2. Corso di italiano. Libro dello studente con esercizi. Recanati: ELI.

D’Angelo, K., Pedol, D. \& Mazzotta, C. (2012a). Parla con me 2. Corso di lingua e cultura italiana per ragazzi (A2 juniores). Firenze: Alma.

D’Angelo, K., Pedol, D. \& Vanoli, L. (2012b). Parla con me 1. Corso di lingua e cultura italiana per ragazzi (A1 juniores). Firenze: Alma.

De Biasio, M. \& Garofalo, P. (2008). Mosaico Italia. Percorsi nella cultura e nella civiltà italiana (B2/C2). Roma: Edilingua.

De Giuli, A., Guastalla, C. \& Naddeo, C. M. (2008). Magari. Corso di lingua e cultura italiana di livello intermedio e avanzato (B1/C1). Firenze: Alma.

De Giuli, A., Guastalla, C. \& Naddeo, C. M. (2013a). Nuovo magari. Corso di lingua e cultura italiana di livello intermedio e avanzato (B2). Firenze: Alma.

De Giuli, A., Guastalla, C. \& Naddeo, C. M. (2013b). Nuovo magari. Corso di lingua e cultura italiana di livello intermedio e avanzato (C1/C2). Firenze: Alma.

De Savorgnani, G. \& Bergero, B. (2010). Chiaro! corso di italiano. Libro dello studente ed eserciziario (A1). Firenze: Alma.

De Savorgnani, G. \& Cordera Alberti, C. (2011). Chiaro! corso di italiano. Libro dello studente ed eserciziario (A2). Firenze: Alma.

De Savorgnani, G. \& Cordera Alberti, C. (2012). Chiaro! corso di italiano. Libro dello studente ed eserciziario (B1). Firenze: Alma. 
Diaco, M., Parma, V. \& Ritondale Spano, P. (2007). Caffè Italia 3. Corso di italiano. Libro dello studente con esercizi. Recanati: ELI.

Errico, R., Esposito, M. A. \& Grandi, N. (2008). Campus Italia, volume 1. Corso multimediale di italiano per le università (A1/A2). Perugia: Guerra.

Faraci, C., De Luca, P. \& Colombo, F. (2011a). Arrivederci! 1. Corso multimediale di italiano per stranieri (A1). Roma: Edilingua.

Faraci, C., De Luca, P. \& Colombo, F. (2011b). Arrivederci! 2. Corso multimediale di italiano per stranieri (A2). Roma: Edilingua.

Faraci, C., De Luca, P., Biagi, D. \& Colombo, F. (2012). Arrivederci! 3. Corso multimediale di italiano per stranieri $(B 1 / B 1+)$. Roma: Edilingua.

Fragai, E., Fratter, I. \& Jafrancesco, E. (2010). Uni.Italia: corso multimediale di lingua italiana per studenti universitari (livello B1/B2). Milano: Mondadori/Le Monnier.

Ghezzi, C., Piantoni, M. \& Bozzone Costa, R. (2009). Contatto 2B. Corso di italiano per stranieri. Livello post-intermedio (B2). Torino: Loescher.

Gruppo lingua (2008). Italiano: pronti, via! 1. Corso multimediale d'italiano per stranieri. Perugia: Guerra.

Gruppo lingua (2009). Italiano: pronti, via! 2. Corso multimediale d'italiano per stranieri. Perugia: Guerra.

Gruppo Meta (Blini, L., Matte Bon, F., Nencini, R. \& Santoni, N.) (1992). Uno: corso comunicativo di italiano per stranieri (primo livello). Roma: Bonacci.

Gruppo Meta (Blini, L., Matte Bon, F., Nencini, R. \& Santoni, N.) (1993). Due: corso comunicativo di italiano per stranieri (secondo livello). Roma: Bonacci.

Guastalla, C. \& Naddeo, C. M. (2010). Domani 1. Corso di lingua e cultura italiana. Firenze: Alma.

Guastalla, C. \& Naddeo, C. M. (2011). Domani 2. Corso di lingua e cultura italiana. Firenze: Alma.

Guastalla, C. \& Naddeo, C. M. (2012). Domani 3. Corso di lingua e cultura italiana. Firenze: Alma.

Ignone, A. (2002). Primi piani sugli italiani: testo di lettura di lingua e civiltà italiana per stranieri (livello intermedio e avanzato). Perugia: Guerra.

Jeremić, T. \& Turconi, S. (1976). Italijanski 1. Beograd: Kolarčev narodni univerzitet.

Jeremić, T. \& Turconi, S. (1977). Italijanski 2. Beograd: Kolarčev narodni univerzitet.

Jones, T. \& Marmini, P. (1998). Comunicando s'impara: esperienze comunicative, libro dello studente. Roma: Bonacci.

Katerinov, K. \& Boriosi, M. C. (1973). La lingua italiana per stranieri con le 3000 parole più usate nell'italiano d'oggi (corso elementare ed intermedio). Perugia: Guerra.

Katerinov, K. \& Boriosi Katerinov, M. C. (1992). Bravo! Corso di lingua italiana e civiltà (livello elementare e avanzato). Milano: Mondadori. 
La Cara, G. \& Preziuso, C. (1998). Il dolce "sì”. Corso di italiano per stranieri. II livello. Manuale per lo studente. Perugia: Guerra.

La Grassa, M. (2011). L'italiano all'università 1. Corso di lingua per studenti stranieri (A1/A2). Roma: Edilingua.

La Grassa, M., Delitala, M. \& Quercioli, F. (2013). L'italiano all'università 2. Corso di lingua per università e istituti di lingua (B1/B2). Roma: Edilingua.

Luraghi, S. \& Venier, F. (2009). Esercizi di semantica, pragmatica e linguistica testuale. Roma: Carocci.

Marin, T. (2000). La Prova Orale 1. Materiale autentico per la conversazione e la preparazione agli esami orali (livello elementare - preintermedio, A1/ B1). Roma: Edilingua.

Marin, T. (2005). La Prova Orale 2. Materiale autentico per la conversazione e la preparazione agli esami orali (livello intermedio - avanzato, B2/C2). Roma: Edilingua.

Marin, T. (2008). Nuovo progetto italiano 3. Corso multimediale di lingua e civiltà italiana. Livello intermedio-avanzato (B2/C1). Libro dello studente. Roma: Edilingua.

Marin, T. \& Magnelli, S. (2001). Progetto italiano 1. Corso di lingua e civiltà italiana. Livello elementare-intermedio. Roma: Edilingua.

Marin, T. \& Magnelli, S. (2003). Progetto italiano 2. Corso di lingua e civiltà italiana. Livello intermedio-medio. Roma: Edilingua.

Marin, T. \& Magnelli, S. (2004). Progetto italiano 3. Corso di lingua e civiltà italiana. Livello medio-avanzato. Testi ed esercizi. Roma: Edilingua.

Marin, T. \& Magnelli, S. (2006). Nuovo progetto italiano 1. Corso multimediale di lingua e civiltà italiana. Livello elementare (A1/A2). Libro dello studente. Roma: Edilingua.

Marin, T. \& Magnelli, S. (2009). Nuovo progetto italiano 2. Corso multimediale di lingua e civiltà italiana. Livello intermedio (B1/B2). Libro dello studente. Roma: Edilingua.

Marin, T. \& Albano, A. (2011a). Progetto italiano Junior 1. Corso multimediale di italiano per adolescenti (livello elementare, A1). Libro di classe e quaderno degli esercizi. Roma: Edilingua.

Marin, T. \& Albano, A. (2011b). Progetto italiano Junior 2. Corso multimediale di lingua e civiltà italiana (livello elementare, A2). Libro di classe e quaderno degli esercizi. Roma: Edilingua.

Marin, T. \& Albano, A. (2012). Progetto italiano Junior 3. Corso multimediale di lingua e civiltà italiana (livello intermedio, A2+). Libro di classe e quaderno degli esercizi. Roma: Edilingua.

Marimi, P. \& Vicentini, G. (1998). Passeggiate italiane. Lezioni di italiano, livello intermedio. Roma: Bonacci. 
Mezzadri, M. (2000). Grammatica essenziale ella lingua italiana con esercizi. Testo di grammatica per studenti stranieri dal livello elementare all'intermedio. Perugia: Guerra.

Mezzadri, M. \& Balboni, P. E. (2000). Rete! 1. Corso multimediale d'italiano per stranieri (libro di classe). Perugia: Guerra.

Mezzadri, M. \& Balboni, P. E. (2001). Rete! 2. Corso multimediale d'italiano per stranieri (libro di classe). Perugia: Guerra.

Mezzadri, M. \& Balboni, P. E. (2002). Rete! 3. Corso multimediale d'italiano per stranieri (libro di classe). Perugia: Guerra.

Mezzadri, M. \& Balboni, P. E. (2005a). Rete! Junior. Corso multimediale d'italiano per stranieri (parte A). Perugia: Guerra.

Mezzadri, M. \& Balboni, P. E. (2005b). Rete! Junior. Corso multimediale d'italiano per stranieri (parte B). Perugia: Guerra.

Naddeo, C. M. \& Trama, G. (2000). Canta che ti passa: imparare l'italiano con le canzoni. Firenze: Alma.

Orlandino, E., Rizzo, G. \& Ziglio, L. (2005). Espresso ragazzi 1. Corso di italiano (A1). Libro dello studente e esercizi. Firenze: Alma.

Patota, G. \& Romanelli, N. (2008a). Percorso Italia. Corso multimediale di lingua italiana per stranieri (A1/A2). Novara: De Agostini.

Patota, G. \& Romanelli, N. (2008b). Percorso Italia. Corso multimediale di lingua italiana per stranieri (B1/B2). Novara: De Agostini.

Perini, S. (1991). Parliamo insieme l'italiano. Primo livello 1. Testo per corsi di lingua e cultura italiana all'estero. Firenze: Giunti.

Piantoni, M., Ghezzi, C. \& Bozzone Costa, R. (2007). Contatto 2A. Corso di italiano per stranieri. Livello intermedio (B1). Torino: Loescher.

Piotti, D. \& De Savorgnani, G. (2006). UniversItalia: corso di italiano (A1/B1). Firenze: Alma.

Radicchi, S. \& Mezzedimi, M. (1989). Corso di lingua italiana. Livello elementare. Roma: Bonacci.

Ricci, M. (2011). Via della grammatica. Teoria, esercizi, test e materiale autentico per stranieri (A1/B2, elementare - intermedio). Roma: Edilingua.

Riggenbach, H. (1999). Discourse Analysis in the Language Classroom. The Spoken Language, vol. 1. Ann Arbor, MI: University of Michigan Press.

Roncari, A. \& Brighenti, C. (1972). La lingua italiana insegnata agli stranieri. Verona: Mondadori.

Rossi-Hace, F. \& Zaina, E. (1983). L'italiano per Lei. Parte quarta. Corso di lingua italiana. Zagreb: Škola za strane jezike.

Rossi-Hace, F. \& Zaina, E. (1988). L'italiano per Lei. Parte terza. Corso audiovisivo. Zagreb: Škola za strane jezike.

Rossi-Hace, F. \& Zaina, E. (1989a). L'italiano per Lei. Parte prima. Corso audio-visivo. Zagreb: Škola za strane jezike. 
Rossi-Hace, F. \& Zaina, E. (1989b). L'italiano per Lei. Parte seconda. Corso audio-visivo. Zagreb: Škola za strane jezike.

Silvestrini, M., Bura, C., Chiacchella, E., Giunti Armanni, V. \& Pavese, R. (1995). L'italiano e l'Italia. Lingua e civiltà per Stranieri. Livello medio e superiore. Grammatica con note di stile. Perugia: Guerra.

Silvestrini, M., Bura, C., Chiacchella, E., Giunti Armanni, V. \& Pavese, R. (1996). L'italiano e l'Italia. Lingua e civiltà per Stranieri. Livello medio e superiore. Esercizi e prove per la certificazione. Perugia: Guerra.

Stipčević, N. \& Franchi, E. (1996). Osnovi italijanskog jezika. Beograd: Prosveta.

Stojković, J. \& Zavišin, K. (2013). Amici 4. Italijanski jezik za osmi razred osnovne škole. Četvrta godina učenja. Beograd: Zavod za udžbenike.

Tamponi, A.-R. (2006). Italiano a modello 1: dalla letteratura alla scrittura, livello elementare e intermedio (A1/B1). Roma: Bonacci.

Terić, G. (1996a). In italiano 1. Priručnik kontrastivne gramatike za govornike srpskog jezika. Perugia: Guerra.

Terić, G. (1996b). In italiano 2. Priručnik kontrastivne gramatike za govornike srpskog jezika. Perugia: Guerra.

Torchia, R. (1997). Testi e parole. Testi scritti e testi orali. Teoria e pratica delle grammatica italiana per studenti stranieri. Livello medio e superiore. Perugia: Guerra.

Vučo, J. \& Moderc, S. (1994). Il mio italiano. Italijanski jezik (prva godina učenja). Podgorica: Zavod za udžbenike i nastavna sredstva.

Vučo, J. \& Moderc, S. (1995). Il mio italiano. Italijanski jezik (druga godina učenja). Podgorica: Zavod za udžbenike i nastavna sredstva.

Vučo, J. \& Moderc, S. (1997). Il mio italiano. Italijanski jezik (treća godina učenja). Podgorica: Zavod za udžbenike i nastavna sredstva.

Vučo, J. \& Moderc, S. (1999). Il mio italiano. Italijanski jezik (četvrta godina učenja). Podgorica: Zavod za udžbenike i nastavna sredstva.

Vučo, J. \& Moderc, S. (2003). Insieme! Italijanski jezik za 1. razred osnovne škole. Beograd: Zavod za udžbenike i nastavna sredstva.

Vučo, J. \& Moderc, S. (2004). Insieme! Italijanski jezik za 2. razred osnovne škole. Beograd: Zavod za udžbenike i nastavna sredstva.

Vučo, J. \& Moderc, S. (2005). Insieme! Italijanski jezik za 3. razred osnovne škole. Beograd: Zavod za udžbenike i nastavna sredstva.

Zamora, P., Arianna, A., Ioppoli, E. \& Simone, F. (2006). Hai voluto la bicicletta... Esercizi su fraseologia e segnali discorsivi per studenti di italiano $L S / L 2$. Perugia: Guerra.

Ziglio, L. \& Rizzo, G. (2001). Espresso 1. Corso di italiano. Libro dello studente ed esercizi. Firenze: Alma.

Ziglio, L. \& Rizzo, G. (2014). Nuovo Espresso 1: corso di italiano (A1). Libro dello studente e esercizi. Firenze: Alma. 
Zurula, M. (1998). Sapore d'Italia. Antologia di testi sulla cultura italiana con esercitazioni orali e scritte. Livello intermedio (B1/B2). Roma: Edilingua.

Živković-Mandolfo, R. (1960). Udžbenik italijanskog jezika sa lektirom. Beograd: Naučna knjiga.

Nevena P. Ceković

\section{Summary \\ TEACHING MATERIALS FOR L2 ITALIAN: (NON) EXPLICIT FOCUS ON DISCOURSE MARKERS}

By analyzing 110 textbooks for L2 Italian and teaching manuals, published within more than 50 years, we discovered that only $10 \%$ of the textbooks, created approximately in the last decade and dedicated exclusively to the intermediate and advanced levels of competence, are focused explicitly on discourse markers (DM). We believe that the Common European Framework marked a milestone towards the introduction of these conversational elements into the textbooks: only in those dating after 2001, the year of the Framework publishing, the DM became the object of an explicit attention. The exception to the widespread practice of offering only few and sporadic acitivites with DM, mostly in only one didactic unit, is reppresented by the 5 textbooks described in this paper, which follow the traditional pattern of Presentation-Practice-Production through various presentational, analytical and productive activities aiming mostly at matching forms and functions of DM, as well as some others, like reflection, role-play or dramatization. Although we consider these textbooks as examples of balanced frequency and cyclicity in the treating of the DM, we can still conclude that such textbooks and their authors are still rare and the quantity of attention dedicated to DM in these materials is insufficient, in terms of a limited number and scope of the proposed activities, as well as the absence of a more explicit focus.

Key words: discourse markers, L2 Italian, teaching materials. 